\title{
Aplikasi Model Adaptasi Roy pada Klien Resiko Perilaku Kekerasan dengan Penerapan Asertiveness Training di RS Dr. H. Marzoeki Mahdi Bogor
}

\author{
Ira Erwina ${ }^{a}$ \\ aprogram Studi Ilmu Keperawatan Universitas Andalas
}

\begin{abstract}
Violens or high risk of violence is one of positive symptom from schyzoprenia (Kaplan \& Sadock, 1997). Assertiveness training can decrease violence behavior at client with Schizoprenia (Wahyuningsih, 2009). The goal of this scientific paper is to describe the nursing care for client with high risk of violence by using Roy's adaptation model. Assertiveness training is done for 23 clients along with general therapy and psychoeducational therapy in Utari and Srikandi room at range of time 14 February - 15 April 2011. Result of of assertiveness training very effective at 23 clients and show improvement in preventing behavior of violens. Based on the result, it's important to recommended that assertiveness training can be made standard of therapy of nursing specialist and require to be socialized at all of health service
\end{abstract}

Key Words : assertiveness training, Roy adaptation model, high risk of violence

\begin{abstract}
Abstrak : Perilaku kekerasan atau risiko perilaku kekerasan adalah salah satu gejala positif dari skizoprenia (Kaplan \& Sadock, 1997). Asertiveness training dapat menurunkan perilaku kekerasan pada klien Skizoprenia (Wahyuningsih, 2009). Tujuan penulisan karya ilmiah akhir ini adalah menggambarkan penatalaksanaan asuhan keperawatan dengan pendekatan model adaptasi Roy pada klien dengan risiko perilaku kekerasan. Penerapan assertiveness training dilakukan pada 23 orang klien di ruang Utari dan Srikandi pada kurun waktu 14 Pebruari - 15 April 2011. Hasil assertiveness training sangat efektif pada 23 klien menunjukkan peningkatan dalam mencegah perilaku kekerasan. Berdasarkan hasil di atas perlu direkomendasikan bahwa assertiveness training dapat dijadikan standar terapi spesialis keperawatan jiwa dan perlu disosialisasikan pada seluruh tatanan pelayanan kesehatan.
\end{abstract}

Kata kunci : asertiveness training, risiko perilaku kekerasan, model adaptasi Roy

\begin{abstract}
American Psychiatric Association (APA) tahun 1995 menyebutkan $1 \%$ dari populasi penduduk dunia menderita gangguan jiwa berupa skizofrenia, jumlahnya tiap tahun makin bertambah dan menimbulkan dampak bagi keluarga dan masyarakat berupa beban ekonomi dan menurunnya kualitas hidup (Sadock \& Sadock, 2005). Berdasarkan laporan WHO tahun 2001, menyebutkan bahwa skizofrenia menyebabkan tingkat ketergantungan klien secara ekonomi yang tinggi yaitu sebesar 2,6\%. Dari data tersebut
\end{abstract}

menunjukkan bahwa walaupun prevalensi skizofrenia tidak begitu besar namun merupakan merupakan masalah yang cukup serius karena menimbulkan dampak bagi keluarga dan masyarakat berupa ketergantungan dalam hal ekonomi. Untuk itu perlu penanganan yang tepat pada klien dengan masalah skizofrenia.

Varcarolis, Carson dan Shoemaker (2006) menyebutkan skizofrenia merupakan penyakit kerusakan otak yang berdampak pada kemampuan berpikir, bahasa, emosi, perilaku sosial, dan kemampuan untuk merasakan realita 
secara akurat. Penjelasan di atas menggambarkan bahwa skizofrenia yaitu gangguan jiwa akibat kerusakan otak yang mengakibatkan gangguan fungsi kognitif, afektif, bahasa, gangguan memandang terhadap realitas, dan hubungan interpersonal.

Gejala mayor skizofrenia digolongkan menjadi dua yaitu gejala positif dan negatif. Gejala positif yang muncul yaitu halusinasi (90\%), delusi (75\%), waham, perilaku agitasi dan agresif, serta gangguan berpikir dan pola bicara. Gejala negatif yaitu afek datar, alogia (sedikit bicara), apatis, penurunan perhatian dan penurunan aktifitas sosial (Varcarolis, Carson \& Shoemaker, 2006; Slowik, 2011). Paparan di atas menyebutkan bahwa perubahan perilaku seperti perilaku agitasi dan agresif atau yang sering dikenal dengan istilah perilaku kekerasan merupakan salah satu gejala positif yang ditemui pada klien skizofrenia.

Perilaku kekerasan merupakan ekspresi kekuatan fisik dengan menyerang diri sendiri atau orang lain, serta pemaksaan keinginan seseorang kepada orang lain (Townsend, 2009). Berdasarkan uraian di atas dapat disimpulkan bahwa perilaku kekerasan merupakan bentuk kekerasan dan pemaksaan secara fisik maupun verbal yang ditujukan kepada diri sendiri maupun orang lain.

Penatalaksanaan klien dengan masalah perilaku kekerasan di pelayanan kesehatan diberikan oleh tenaga kesehatan. Perawat sebagai salah satu bagian dari pemberi layanan kesehatan pada klien melakukan asuhan keperawatan dalam membantu kesembuhan klien. Untuk klien dengan masalah perilaku kekerasan, asuhan keperawatan klien diberikan dalam bentuk asuhan keperawatan generalis dan spesialis. Asuhan keperawatan yang diberikan pada individu dengan perilaku kekerasan dapat berupa tindakan keperawatan generalis dan spesialis (FIK-UI, 2009). Keliat (2003), menyebutkan bahwa pemberian tindakan keperawatan generalis untuk perilaku kekerasan menghasilkan kemampuan mencegah perilaku kekerasan secara mandiri sebesar $86,6 \%$ dan secara signifikan menurunkan perilaku kekerasan.

Penelitian yang dilakukan oleh Wahyuningsih (2009) membuktikan bahwa terjadi penurunan sebesar $87,4 \%$ respon perilaku, sosial dan kognitif pada klien yang diberikan terapi generalis dan asertiveness training jika dibandingkan dengan klien yang hanya diberikan terapi generalis saja. Ini menunjukkan bahwa dengan pemberian asertiveness training dan terapi generalis terbukti lebih baik dari pada diberikan terapi generalis saja.

Hal tersebut mendasari ketertarikan penulis untuk melakukan analisis lebih lebih lanjut mengenai masalah keperawatan risiko perilaku kekerasan, karena banyak kasus yang masuk ke rumah sakit dengan perilaku kekerasan. Sehingga perlu diketahui apakah asertiveness training mampu meningkatkan kembali kemampuan klien dan masalah perilaku kekerasannya hilang atau berkurang dan melaporkannya dalam suatu karya ilmiah.

Tujuan umum yang diharapkanMemberikan gambaran tentang asuhan keperawatan spesialis jiwa : risiko perilaku kekerasan dengan penerapan asertiveness training melalui pendekatan model adaptasi Roy di RS. Dr. H. Marzoeki Mahdi Bogor. Sedangkan tujuan khusus untuk mengetahui implikasi asertiveness training dengan pendekatan model adaptasi Roy pada klien dengan resiko perilaku kekerasan di RS. Dr. Marzoeki Mahdi Bogor.

\section{PEMBAHASAN}

Perilaku kekerasan muncul karena adanya dorongan alami atau timbul sebagai bentuk mekanisme koping yang dimanifestasikan dengan tindakan konstruktif atau destruktif yang secara langsung ditujukan pada diri sendiri atau orang lain. Perilaku kekerasan biasanya berupa kekerasan secara fisik atau kekerasan secara verbal. Perilaku kekerasan biasanya timbul untuk menutupi kekurangan seseorang, misalnya rendahnya percaya diri (Townsend, 2009).

Proses terjadinya perilaku kekerasan ini dapat diuraikan terlebih dahulu dari 
proses terjadinya gangguan jiwa itu sendiri yang dihubungkan dengan perilaku kekerasan. Stuart dan Laraia (2005) menggambarkan dua dimensi yang dapat menjelaskan proses terjadinya gangguan jiwa yaitu meliputi faktor predisposisi dan faktor presipitasi. Faktor predisposisi adalah faktor risiko yang dipengaruhi oleh jenis dan jumlah sumber risiko yang dapat menyebabkan individu mengatasi stres. Faktor predisposisi yang menjadi penyebab perilaku kekerasan dikaitkan dengan faktor biologis, psikologis dan sosial budaya (Stuart \& Laraia, 2005; Varcarolis, Carson \& Shoemaker, 2006). Faktor presipitasi adalah stimulus (sressor) yang merubah atau menekan sehingga memunculkan gejala saat ini (Stuart \& Laraia, 2005). Faktor ini meliputi empat hal yaitu sifat stresor, asal stresor, waktu stresor yang dialami, dan banyaknya stresor yang dihadapi oleh seseorang.

Gejala-gejala yang terlihat pada klien dengan perilaku kekerasan tidak dialami oleh semua orang yang didiagnosis dengan skizofrenia. Pada klien dengan perilaku kekerasan terlihat adanya gejala positif dari empat dimensi utama gejala skizofrenia. Ketika Individu mendapatkan stressor dalam faktor predisposisi maupun presipitasi yang berasal dari biologis, psikologis maupun sosiokultural akan berlanjut pada proses penilaian terhadap stressor tersebut. Penilaian stresor adalah proses dari situasi stres yang komprehensif yang berada pada beberapa tingkatan. Secara spesifik proses ini melibatkan respon kognitif, respon afektif, respon fisiologis, respon perilaku dan respon sosial (Stuart \& Laraia, 2005).

Risiko perilaku kekerasan merupakan salah satu masalah keperawatan yang sering ditemui pada klien yang dirawat di rumah sakit. Intervensi yang diberikan pada klien dapat berupa intervensi keperawatan dan intervensi medis. Stuart dan Laraia (2005) menyebutkan bahwa perawat dapat melakukan berbagai macam tindakan untuk mencegah dan mengatasi perilaku kekerasan. Intervensi ini dapat digambarkan dalam suatu rentang dimana salah satu sisi adalah strategi preventif, dan pada sisi lainnya adalah strategi antisipasi. Jika perilaku kekerasan klien lebih luas dari rentang yang ada, maka perawat perlu menerapkan teknik manajemen krisis dan strategi penahanan seperti pengasingan (isolasi) dan pengekangan. Assertiveness training termasuk salah satu strategi preventif yang dilakukan untuk klien mencegah terjadinya perilaku kekerasan kembali. Dapat disimpulkan bahwa strategi preventif perilaku kekerasan yaitu peningkatan kesadaran diri perawat, edukasi, dan terapi spesialis assertiveness training.

Assertiveness training merupakan tindakan untuk melatih seseorang mencapai perilaku asertif (Sadock \& Sadock, 2005). Assertiveness training merupakan program latihan perilaku untuk melatih seseorang menyampaikan kebutuhan, hak, dan menentukan pilihan tanpa mengabaikan hak orang lain (Forkas,1997 dalam Wahyuningsih, 2009). Assertiveness training diberikan pada kondisi individu tertekan, manipulatif dan agresif (Hopkins, 2005), keadaan depresi, marah, frustasi, kecemasan, keterbatasan hubungan sosial, masalah fisik dan masalah dalam pola asuh, riwayat perilaku kekerasan, kecemasan sosial (Sadock \& Sadock, 2007) dan konsep diri rendah. Tujuan akhir yang diharapkan pada pemberian assertiveness training yaitu membentuk rentang perilaku yang adaptif yaitu perilaku asertif (Sadock \& Sadock, 2005).Pelaksanaan assertiveness training dikembangkan berdasarkan prinsip ketrampilan yang harus dimiliki dalam assertiveness training. Berdasarkan penerapan assertiveness training yang telah dikembangkan sebelumnya, yaitu dari Stuart dan Laraia (2005) dan Vinick (1983 dalam Wahyuningsih, 2009), maka tehnik pelaksanaan assertiveness training meliputi lima yaitu describing, modelling, role playing, feedback, transferring.

Model adaptation milik Roy ini berkembang dari teori adaptasi oleh Helson (Tomey \& Alligood, 2006). Menurut Roy 
(1984 dalam Tomey \& Alligood, 2006) stimulus adalah segala sesuatu yang akan mendorong timbulnya respon. Roy membagi tingkatan adaptasi berdasarkan efek yang ditimbulkan dari stimulusstimulus, yaitu 1) fokal stimulus, semua stimulus yang langsung menyerang individu. 2) kontekstual stimulus, semua stimulus yang ada pada saat itu, yang berkontribusi terhadap efek dari stimulus fokal, 3) residual stimulus, faktor lingkungan yang memberi efek terhadap situasi tertentu. Level adaptasi menggambarkan kondisi proses kehidupan dalam tiga tingkatan, yaitu integrated, compensatoy dan compromised.

Konsep dasar yang dipergunakan untuk melakukan pengkajian adalah model adaptasi Roy, pengkajian ini merupakan langkah untuk melihat input yaitu stimulus fokal, kontekstual dan residual yang ada pada klien dengan risiko perilaku kekerasan. Teknik pengkajian yang dilakukan yaitu dengan pendekatan Model Stres Adaptasi Stuart. Berikut ini hasil pengkajian pada klien yang diberikan asertiveness training di Ruang Utari dan Srikandi RSMM periode 14 Pebruari - 15 April 2011.

Karakteristik klien jika dikaitkan pada model Adaptasi Roy merupakan stimulus kontekstual. Hal ini karena karakteristik klien bukan stimulus yang langsung, tapi mempengaruhi stimulus fokal. Hasil menunjukkan bahwa sebagian klien dengan pendidikan SLTA $(52,2 \%)$, status pekerjaan klien yang terbanyak adalah tidak bekerja $(59,6 \%)$, kondisi status ekonomi klien sebagian besar adalah jamkesmas/jamkesda (60,8\%), lamanya klien mengalami sakit sebagian besar lebih dari 5 tahun (78,3\%), usia rentang 20-40 tahun sebanyak $60,8 \%$, dan sebagian dari klien tidak menikah $(56,5 \%)$. menunjukkan bahwa sebagian klien dengan pendidikan SLTA $(52,2 \%)$, status pekerjaan klien yang terbanyak adalah tidak bekerja $(59,6 \%)$, kondisi status ekonomi klien sebagian besar adalah jamkesmas/jamkesda (60,8\%), lamanya klien mengalami sakit sebagian besar lebih dari 5 tahun $(78,3 \%)$, usia rentang 20-40 tahun sebanyak 60,8\%, dan sebagian dari klien tidak menikah $(56,5 \%)$.

Faktor predisposisi merupakan stimulus kontekstual dan residual pada model adaptasi Roy ini. Karena faktor predisposisi ini memberikan pengaruh pada stimulus fokal. Faktor biologis; sebagian besar klien mengalami masalah genetik sekitar 64,3\%, dan riwayat menggunakan NAPZA sekitar 17,9\%. Faktor psikologis; sebagian besar dengan masalah pola komunikasi tertutup (92,9\%), sebagian kasus atau separuhnya mempunyai kepribadian introvert $(47,8 \%)$ dan mengalami masalah kehilangan objek yang dicintai (rata-rata 56,5\%). Faktor sosial budaya: aspek sosial ekonomi hampir semua kelompok klien termasuk dalam kategori tidak mampu atau biaya perawatan dengan asuransi kesehatan (60,9\%) dan juga mengalami masalah dalam pekerjaan, yaitu tidak bekerja atau mengalami PHK sekita $56,5 \%$. Faktor lain adalah kurangnya mengikuti kegiatan sosial $(39,1 \%)$, dan ada masalah dalam perkawinan sekitar $60,9 \%$.

Faktor presipitasi merupakan stimulus fokal atau faktor yang mengancam individu secara langsung. Stimulus fokal merupakan bagian dari input. Pada faktor presipitasi sifat stresor secara psikologis, semua klien mengalami kegagalan dalam rentang kehidupannya (100\%), putus obat $(86,9 \%)$ dan pencetus dari faktor hubungan sosial (sosial budaya) juga sama, semua klien mengalaminya (100\%). Sementara itu berkaitan dengan sumber stresor yang dialami klien semua klien mendapati sumber stresor dari faktor internal klien sendiri $(100 \%)$ dan hanya sebagian saja yang benar-benar karena sumber eksternal. Artinya walaupun klien juga mendapat stresor dari lingkungan tetapi aspek kognitif dan afektif diri klien yang paling berperan menimbulkan masalah. Sementara itu berkaitan dengan lamanya gangguan klien sebagian besar telah mengalami gangguan jiwa lebih dari 5 tahun $(78,3 \%)$ dan jumlah stresor yang dialami lebih dari satu $(91,3 \%)$.

Penilaian terhadap stressor pada model adaptasi Roy masuk, pada stimulus 
fokal, karena data-data yang didapatkan pada penilaian terhadap stressor merupakan respon klien terhadap masalah yang dihadapinya. Secara kognitif, pada seluruh kasus yang ditemukan klien merasa memandang negatif terhadap stresor dan merasa tidak mempunyai kemampuan untuk mengatasi masalahnya, serta berpikir untuk menggunakan koping yang tidak adaptif. Secara afektif, pada semua kasus yang ditemukan (100\%) klien merasa mudah putus asa, mudah tersinggung (marah) dan mudah menyerah saat meghadapi suatu masalah. Sedangkan respon fisiologis pada sebagian besar kasus tidak ditemukan secara spesifik, artinya pada sebagian kasus saat dilakukan pemeriksaan tanda vital dalam batas normal, kecuali pada klien yang mempunyai masalah fisik penyerta seperti gagal ginjal, dan penyakit anemia. Pada perilaku; respon perilaku klien separuhnya menunjukkan perilaku tidak mampu mengungkapkan masalah secara efektif, cenderung negatif berupa ungkapan marah baik verbal maupun pasif, tidak berani mengungkapkan pendapat, tidak mampu memulai pembicaraan, sering melamun, tidak suka bergaul, mengungkapkan bahwa dirinya jelek, merasa tidak berharga, merasa tidak bisa apa-apa. Perilaku lain yang nampak, ditemukan pada sebagian besar kasus berupa perilaku mudah menyerah, mudah putus asa, dan ragu-ragu dalam mengambil keputusan atau dalam melakukan tindakan. Sedangkan secara sosial, sebagian besar klien cenderung menyendiri dan bersikap pasif dalam mengatasi masalah dan menunjukkan sikap agresif.

Sumber koping pada model adaptasi Roy merupakan kategori dari stimulus residual. Pada sumber koping kita bisa melihat nilai yang dipakai oleh klien atau keyakinan yang diyakini. Selain masuk dalam stimulus residual sebagai input, juga termasuk proses kontrol, yaitu mekanisme koping : kognator. Kemampuan personal, sebagian besar klien telah memiliki kemampuan untuk mengatasi masalah risiko perilaku kekerasan. Sebagian besar klien juga mengungkapkan kurang mampu terbuka pada orang lain, sehingga kurang mampu mengungkapkan ide dan pendapat karena merasa takut ditolak. Terkait dukungan sosial, semua kasus yang ditemukan menunjukkan data adanya dukungan sosial dan keluarga untuk membantu klien dalam mengembangkan kemampuan yang positif. Akan tetapi sebagian besar keluarga belum mengenal masalah, serta cara mengatasinya. Aset ekonomi, sebagian besar $(60,8 \%)$ klien menggunakan jamkesmas/jamkesda untuk biaya perawatan dan pengobatan selama di RSMM. Keyakinan positif, sebagian besar klien mempunyai keyakinan positif terhadap pengobatan yang dijalaninya $(82,6 \%)$.

Mekanisme koping pada model adaptasi Roy masuk stimulus fokal, yaitu respon atau perilaku yang dimunculkan klien pada saat menghadapi masalah. Pada sebagian besar kasus yang ditemukan, mekanisme koping yang dipergunakan adalah untuk masalah risiko perilaku kekerasan adalah denial, proyeksi, dan displacement. Ketiga mekanisme koping tersebut bisa juga disebut sebagai defense mechanism. Hal ini dapat dinilai melalui sikap klien yang cenderung menyalahkan orang lain terhadap apa yang dialami klien.

Diagnosis keperawatan masih merupakan bagian dari input pada model adaptasi Roy. Karena hanya klien dengan masalah risiko perilaku kekerasan saja yang akan diambil sebagai input. Jumlah klien yang diikutsertakan dalam asuhan keperawatan spesialis dengan risiko perilaku kekerasan sebanyak 23 orang dan semuanya mengalami masalah risiko perilaku kekerasan, dan selain risiko perilaku kekerasan diantaranya memiliki masalah keperawatan lain seperti, 22 orang klien diantaranya mengalami halusinasi, 21 orang klien mengalami isolasi sosial, dan 10 orang klien juga mengalami harga diri rendah.

Rencana tindakan berdasarkan SAK yang telah disusun melalui hasil Workshop Keperawatan Jiwa FIK UI (2009) meliputi tindakan keperawatan generalis dan spesialis dengan target pada individu, 
dimana terapi spesialis yang dilakukan adalah asertiveness training.

Semua klien dengan risiko perilaku kekerasan mendapatkan tindakan keperawatan generalis. Berdasarkan hasil ditemukan tidak semua klien dengan risiko perilaku kekerasan mendapatkan asertiveness training sampai selesai. Hal ini disebabkan karena ada hambatan, yaitu klien yang sudah pulang dijemput oleh keluarga dan ada juga klien yang lebih lambat menerima proses pembelajaran. Pelaksanaan asertiveness training pada masalah keperawatan risiko perilaku kekerasan mengikuti dengan sesi-sesi pelaksanaan terapi tersebut yang disesuaikan dengan pokok masalah dari diagnosis keperawatan yang dialami oleh klien.

Evaluasi terhadap hasil tindakan
dilakukan
keperawatan
membandingkan rencana tindakan dengan
pelaksanaan tidakan yang diberikan, yang
meliputi respon kognitif, respon sosial, dan
respon perilaku. Hasil asertiveness training
pada 23 klien; 8(34,8\%) mandiri dan
pulang, 9 orang masih dirawat.

\section{PEMBAHASAN}

Penerapan model adaptasi Roy untuk mengatasi masalah risiko perilaku kekerasan dapat digunakan dengan baik. Perilaku kekerasan atau semua respon yang ada pada klien dengan risiko perilaku kekerasan merupakan input (stimulus fokal). Sedangkan karakteristik klien merupakan stimulus kontekstual, dan faktor predisposisi dan presipitasi merupakan stimulus kontekstual dan residual. Hasil pengkajian pada klien dengan risiko perilaku kekerasan akan dikelompokkan pada stimulus-stimulus dalam model adaptasi Roy.

Proses kontrol pada model adaptasi Roy merupakan mekanisme koping yang dimiliki klien. Pada klien risiko perilaku kekerasan, mekanisme yang kita tuju adalah kognator, yaitu masalah kognitif dan emosi. Pada klien risiko perilaku kekerasan mekanisme ini tidak mampu menghasilkan adaptasi yang baik, sehingga timbullah perilaku kekerasan. Tindakan keperawatan yang diberikan berguna untuk memperkuat mekanisme koping kognator klien.

Pemberian asertiveness training ini sesuai dengan konsep model adaptasi Roy, yang diarahkan pada konsep input, proses kontrol, efektor dan output. Intervensi dalam hal ini lebih difokuskan pada asertiveness training yang diberikan oleh perawat dengan tujuan untuk meningkatkan mekanisme koping, yaitu kognator pada klien resiko perilaku kekerasan dalam menyelesaikan masalahnya.

\section{KESIMPULAN}

Model adaptasi Roy mampu mengakomodasi asuhan keperawatan pada klien dengan risiko perilaku kekerasan, karena model ini mengembangkan adaptasi individu terhadap stressor. Perilaku kekerasan merupakan proses adaptasi yang tidak efektif, jika efektif maka perilaku ini tidak terjadi. Untuk instansi pelayanan, menetapkan kebijakan terkait dengan program pelayanan keperawatan spesialistik khususnya penerbitan standar asuhan keperawatan terkait dengan pelaksanaan manajemen kasus spesialis pada asertiveness training untuk masalah resiko perilaku kekerasan.

\section{DAFTAR PUSTAKA}

American Psychiatrics Assosiation. (2000). Diagnostic \& statistical manual of mental disorders. ( $4^{\text {th }}$ ed). Januari 17, 2010. Washington: APA.

Basmanelly. (2009). Pengaruh asertif training dan latihan kemampuan sosial pada klien dengan perilaku kekerasan di ruang kresna rsmm bogor. KIA. FIK UI. Tidak dipublikasikan.

Boyd, M.A. \& Nihart, M.A. (1998). Psychiatric Nursing Contemporary Practice. USA: Lippincott Raven Publisher. 
Cristopher, E. (2010), Anger, agression, and irrational beliefs in adolescents, Cogn Ter Res. Springer Science LLC.

Depkes. (2004). Keputusan menteri kesehatan republik Indonesia Nomor : 220 / menkes / sk / iii / $2002 \mathrm{Te}$ e $t$ a $n$ g Pedoman umum tim pembina, tim pengarah, tim pelaksana kesehatan jiwa masyarakat (tp kjm). Juni 9, 2011. http://dinkessulsel.go.id/new/images/pdf/Peratura $\mathrm{n} / \mathrm{kmk} \% 20 \mathrm{tp}-$

kesehatan\%20jiwa\%20masyarakat\% 20220-2002.pdf.

Depkes. (2008). Laporan riskesdas. Mei 6, 2011.

http://www.litbang.depkes.go.id/ laporan RKD/Indonesia Nasional.pdf.

Depkominfo. (2009). Undang-undang republik indonesia nomor 36 tahun 2009 tentang kesehatan. Mei 17, 2011.

http://pih.depkominfo.go.id/userfiles /fkk/UU\%2036\%20Tahun\%202009. pdf

Effendy, N. (1998). Dasar-dasar keperawatan kesehatan masyarakat. Edisi dua. Jakarta: EGC.

Fauziah. (2009). Pengaruh terapi perilaku kognitif pada klien skizoprenia dengan perilaku kekerasan, Tesis. Jakarta. FIK UI. Tidak dipublikasikan.

Fitzpatrick, J.J \& Whall, A. L (1989). Conceptual model of nursing analysis and application. ( $\left.2^{\text {nd }} \mathrm{ed}\right)$. Norwalk, Connecticut San Marino, California: Appleton \& Lange.

Fontaine, K.L. (2003). Mental health nursing. New Jersey: Pearson Education, Inc.

Fortinash, K.M. (2000). Psychiatric mental health nursing. ( $3^{\text {rd }}$ ed). St. Louis, Missouri: Mosby-Year Book.

Frisch, N.C. \& Frisch, L.E. (2006). Psychiatric mental health nursing. ( $3^{\text {rd }}$ ed). Canada: Thomson Delmar Learning.
Funk M, et al. (2010). Mental health and development: targeting people with mental health conditions as a vulnerable. Group. Switzerland; WHO Press. Juni 9, 2011, http://whqlibdoc.who.int/publication s/2010/9789241563949_eng.pdf.

Hawari, D. (2001). Pendekatan holistik pada gangguan jiwa skizoprenia. Jakarta : FKUI.

Hood \& Leddy. (2006). Leddy \& pepper conceptual bases of professional nursing. $\quad\left(6^{\text {th }}\right.$ ed $) . \quad$ Philadelphia: Lippincott Williams \& Wilkins.

Hopkins ,L. (2005). http//www. Ezinearticles.com/?assertivecommunication-6 tips-for effecyive use, diunduh tanggal 30 Mei 2011.

Kaplan \& Sadock. (1997). Sinopsis Psikatri ilmu penegetahuan perilaku psikistri klinis. Jilid satu. Edisi ketujuh. Jakarta: Binarupa Aksara.

Kaplan, H.I., Sadock, B.J. \& Grebb, J.A. (1997). Sinopsis psikiatri. (7 ${ }^{\text {th }}$ ed.). Jakarta: Bina Rupa Aksara.

Keliat \& Sinaga. (1991). Asuhan keperawatan pada klien marah. Jakarta : EGC.

Keliat, B.A. (1996). Peran serta keluarga dalam perawatan klien gangguan jiwa. Jakarta: EGC.

Keliat, B.A. (2003). Pemberdayaan klien dan keluarga dalam perawatan klien Skizoprenia dengan perilaku kekerasan di Rumah Sakit Jiwa Pusat Bogor. Disertasi. Jakarta: FKM UI.

Putri, D. E. (2010). Pengaruh rational emotive behaviour therapy terhadap penurunan perilaku kekerasan di ruang rawat inap rsmm bogor. Tesis. Jakarta: FIK UI. Tidak dipublikasikan.

Ramirez \& Andreu. (2005). Aggression, and some related psychological construct (anger,hostility and impulsivity), some comments from a research project. Mei 21, 2011. 
http://eprints.ucm.es/8425/2/Aggress ion_JMR_revised-1.pdf.

Rawlins, Williams \& Beck, C.K. (1993). Mental health-psychiatric nursing. $\left(3^{\text {rd }}\right.$ ed). St. Louis: Mosby Year Book.

Robinson \& Kish. (2001). Core concepts in advance practice nursing. St Louis: Mosby Inc.

Sadock, B. J \& Sadock, V. A. (2005). Kaplan \& sadokc's comprehensive textbook of psychiatry. ( $8^{\text {th }}$ ed). Philadelphia: Lippincotts William \& Wilkins.

Sadock, B. J \& Sadock, V. A. (2007). Kaplan \& sadokc's synopsis of psychiatry: behavioral science/clinical psychiatry. $\left(10^{\text {th }} \mathrm{ed}\right)$. Philadelphia: Lippincotts William \& Wilkins.

Saladino. (2007). Mei 10, 2011 www.proquest umi.com/pqdweb?index.

Shives, L. R. (2005). Basic concepts of psychiatric mental health nursing. $\left(6^{\text {th }}\right.$ ed). Philadelphia: Lippincott Williams \& Wilkins.

Slowik G. (2011). What are the symptoms of skizofrenia?. Juni 9, 2011.

http://ehealthmd.com/library/schizop hrenia/SCH_symptoms.html.

Smith \& Segal. (2011). Coping with grief and loss. Support fot grieving and bereavement. Juni 9, 2011. http://www.helpguide.org/mental/gri ef_loss.htm.

Stuart, G.W \& Laraia, M.T. (2005). Principles and practice of psychiatric nursing. $\left(8^{\text {th }}\right.$ ed). St. Louis: Mosby.

Stuart, G.W., Sundeen, S.J.(2005). Principle and Practice of Psychiatric Nursing, (edisi 4) Philadephia, J.B Lippincot.

Sulastri. (2008). Asuhan keperawatan pada pasien dengan resiko perilaku kekerasan di ruang perawatan Utari. KTI. FIK UI. Tidak dipublikasikan

Tate, Reppuci \& Mulvey. (1995). Violent juvenile delinquents : treatment effectiveness and implications for further action. American Psychologist : Vol 50 No. 9, 777781. Mei 18, 2011, http://www.willamette.edu/cla/debat e/Curriculum/YouthForum2010/KP DCResearch/Motion2Affirmative/N ouraViolent\%20Juvenile\%20Deling uents.pdf

Tomey, M.A \& Alligood, M. R (2006), Nursing Theories and Their Work, $\left(6^{\text {th }}\right.$ ed) St. Louis: Mosby Elsevier.

Townsend, M.C. (2009). Psychiatric mental health nursing. Concepts of care in evidence -based practice. $6^{\text {th }}$ ed. Philadelphia: F.A Davis Company.

Triantoro, S. \& Saputra (2009), Manajemen emosi. Jakarta. Bumi Aksara.

Varcarolis, E.M, Carson, V. B, Shoemaker, N. C. (2006). Foundations of psychiatric mental health nursing: a clinical approach. $\left(5^{\text {th }} \mathrm{ed}\right)$. St. Louis: Saunders Elseviers.

Videbeck, S.L. (2008). Psychiatric mental health nursing. $4^{\text {th }}$ ed. Philadelphia: Wolters Kluwer health. Lippincoatt Williams \& Wilkins.

Videbeck, S. L. (2008). Buku ajar keperawatan jiwa. Jakarta. EGC.

Wahyuningsih, D (2009). Pengaruh assertive trainning terhadap perilaku kekerasan pada klien skizoprenia, Tesis. Jakarta. FIK UI. Tidak dipublikasikan

WHO. (1992). The ICD - 10 Classification of mental and behavioural disorders : clinical description and diagnosis guidelines. Mei 29, 2011

WHO. (2001). The World health report : 2001 : Mental health : new understanding, new hope. Switzerland; WHO Press. Juni 9, 2011.

http://www.who.int/whr/2001/en/wh r01_en.pdf.

Wilkinson, J.M. (2007). Buku saku diagnosis keperawatan dengan intervensi NIC dan kriteria hasil NOC. Edisi 7. Alih bahasa: Widyawati, dkk. Jakarta: EGC. 
Workshop Keperawatan Jiwa FIK UI Xeniditis, Russell \& Murphy. (2001). (2009).

World Federation For Mental health (2008), Management of people with challenging behavior. Advance in Leraning about schizophrenia: an international mental health awareness packet. Mei 8, 2011. Http:///www.wfmh.org. psychiatric treatment. 7:109-116, Mei 18, 2011, http://apt.rcpsych.org/cgi/content/ful 1/7/2/109\#T. 